\title{
ОНОВЛЕННЯ ПРЕДМЕТА ГАЛУЗІ ІНФОРМАЦЙНОГО ПРАВА УКРАЇНИ В РІШЕННЯХ ВЕРХОВНОГО СУДУ: ОКРЕМІ МЕТОДОЛОГІЧНІ І ПРИКЛАДНІ АСПЕКТИ
}

\section{Заярний О. А.}

\section{ВСТУП}

Орієнтація державної політики України на активний розвиток інформаційного суспільства, розширення сфери інформаційної діяльності ${ }^{1}$ передбачає для національного механізму правового регулювання формування нових завдань, у реалізації яких важливе значення належить судовій практиці, перш за все рішенням Верховного Суду.

Значною мірою така тенденція властива національній галузі інформаційного права України. Маючи усі ознаки комплексної галузі права ${ }^{2}$ в останні кілька десятиліть галузь інформаційного права зіткнулась is різними доктринальними, правотворчими i правозастосовчими викликами, відповідь на які вимагає істотного оновлення іiі основних змістоутворюючих компонентів.

Важливою складовою частиною правового фундаменту для вирішення цього завдання виступає практика Верховного Суду, зв'язок з якою дає змогу інформаційному праву та його основним галузевим компонентам набути глибшого практичного змісту. Тим самим галузеві інститути інформаційного права набувають більшої функціональної та інструментарної спроможності реагувати на сучасні зміни в правовому регулюванні інформаційних відносин, формувати ефективні умови для імплементації європейських стандартів інформаційних прав і свобод в норми національного законодавства, а також сферу правозастосування.

Однією зі змістоутворюючих ознак будь-якої галузі права, що визначає іiі сутність, зумовлює місце в системі права, є предмет правового регулювання 3 . Традиційно, в теорії права цим поняттям охоплюється коло однорідних суспільних відносин, які підпадають під дію норм конкретної галузі права ${ }^{4}$.

\footnotetext{
1 Заярний О.А. Інформаційна сфера як об'єкт адміністративно-правової охорони: деякі доктринальні та нормативні аспекти. Журнал східноєвропейського права. № 22. URL: http://easternlaw.com.ua/ uk/osoblive-administrativne-pravo/zayarnij-o-a-informacijna-sfera-yak-obyekt-administrativnopravovo\%D1\%97-oxoroni-deyaki-doktrinalni-ta-normativni-aspekti (дата звернення 29.05.2020).

${ }^{2}$ Бєляков К.І. Інформаційне право: аналіз понятійно-термінологічного апарату. Вісник Національної академії внутрішніх справ. 2007. № 3. С. 67.

3 Загальна теорія права : підручник / За заг. ред. М.І. Козюбри. Київ : Ваіте. 2015. С. 97.

4 Загальна теорія держави і права [Текст] : підручник для студентів юридичних вищих навчальних закладів / [М.В. Цвік, О.В. Петришин, Л.В. Авраменко та ін.]; за ред. д-ра юрид. наук, проф., акад. АПрН України М.В. Цвіка, д-ра юрид. наук, проф., акад. АПрН України О.В. Петришина. Харків : Право. 2009. С. 258.
} 
Щодо інформаційного права, ця галузева ознака піддавалася глибоким науковим дослідженням, результатом яких стало вироблення різних доктринальних підходів до визначення інформаційних відносин у відповідному значенні ${ }^{5,6}$.

Серед дослідників, чиї наукові праці зробили значний внесок у формування предмета галузі інформаційного права, необхідно визначити І.В. Арістову, І.Л. Бачило, К.Є. Бєлякова, О.Д. Довганя, Р.А. Калюжного, О.В. Кохановську, П.У. Кузнецова, Д.О. Марець, І.В. Панову, О.М. Селезньову, І.М. Сопілко, Т.Ю. Ткачука та інших.

Разом із тим істотне зростання кількості справ про порушення інформаційних прав і свобод фізичних та юридичних осіб, переданих на розгляд до Верховного Суду за останніх кілька років, предметна розпорошеність таких спорів по різних судових юрисдикціях зумовлює перед юридичною наукою формування важливого інституційного завдання. Його сутність полягає в необхідності виявити методологічні зв'язки між правовими позиціями Верховного Суду щодо визначення елементів інформаційних відносин та сучасним станом доктринальної розробки поняття «предмет галузі інформаційного права», виявлення на цій основі ключових розбіжностей у теоретичних і правозастосовчих підходах до розуміння змісту відповідних категорій.

Актуальність порушеної проблематики також посилюється у зв'язку із визнанням у нормах законодавства України ${ }^{7,8,9,10}$ за правовими позиціями Верховного Суду значення обов'язкових орієнтирів у розгляді аналогічних справ судами нижчих інстанцій, поряд із відсутністю в рішеннях Верховного Суду єдиного підходу до визначення сутності інформаційних відносин.

Метою цієї роботи є дослідження методологічних та прикладних аспектів впливу правових позицій Верховного Суду на оновлення змісту предмета вітчизняної галузі інформаційного права, формулювання на цій основі критеріїв визначення відповідної правової категорії у практиці найвищого органу судової влади України

\footnotetext{
5 Буріло Ю.П. Про комплексну природу інформаційного права. Інформація $і$ право. 2015. № 1(13). URL: http://ippi.org.ua/sites/default/files/bypkpip_13_1_2015_0.pdf (дата звернення 29.05.2020).

6 Заярний О.А. Правове забезпечення розвитку інформаційної сфери України: адміністративноделіктний аспект : монографія. Херсон : Видавничий дім «Гельветика». 2017. С. 32.

${ }^{7}$ Про судоустрій і статус суддів : Закон України від 02.06.2016 р. № 1402-VIII. Голос України. 2016. № $132 / 133$.

${ }^{8}$ Господарський процесуальний кодекс України від 06.11.1991 р. (редакція від 28.08.2018). URL: https://zakon.rada.gov.ua/laws/show/1798-12. (дата звернення: 29.05.2020).

9 Кодекс адміністративного судочинства України від 06.07.2005 р. (редакція від 04.11.2018). URL: https://zakon.rada.gov.ua/laws/show/2747-15 (дата звернення: 29.05.2020).

${ }^{10}$ Цивільний процесуальний кодекс України : Закон України від 18.03.2004 p. № 1618-IV (редакція від 04.11.2018). URL: https://zakon.rada.gov.ua/laws/show/1618-15 (дата звернення: 29.05.2020).
} 
Предметом дослідження в роботи є правові позиції Верховного Суду, в яких розкриваються елементи предмета галузі інформаційного права, узагальнюються їх окремі властивості, а також наявні в юридичній літературі доктринальні підходи щодо визначення предмета правового регулювання галузі інформаційного права України.

\section{1. Юрисдикція касаційних судів у складі Верховного Суду \\ та елементи інформаційних відносин як критерії оновлення змісту предмета галузі інформаційного права України: проблеми узгодження і взаємозумовленості}

Виступаючи теоретичною основою для формування i оновлення предмета галузі інформаційного права, інформаційні відносини з моменту ïx доктринального оформлення в окреме змістоутворююче поняття зазнали різновекторного доктринального тлумачення ${ }^{11}$. Це знайшло своє відображення не лише у визначенні змісту інформаційних відносин та тенденціях їx подальшого оновлення, але i в доктринальному i правозастосовчому тлумаченні сутності інших елементів, таких як суб'єкт, об'єкт, підстави виникнення, зміни або припинення.

За своєю сутністю інформаційні відносини так само, як і процеси, пов'язані не лише 3 самою інформацією, а й 3 інформаційними технологіями, засобами їх забезпечення, засобами i механізмами забезпечення інформаційної безпеки, тобто, по суті, з технічними засобами створення, обробки і передавання інформації ${ }^{12}$.

На думку І.Л. Бачіло, предметом, що формує спеціальну сферу відносин, які мають умовну назву «інформаційних», є сукупність матеріалізованих результатів творчості і праці, що реально існують і втілені: 1) в інформації

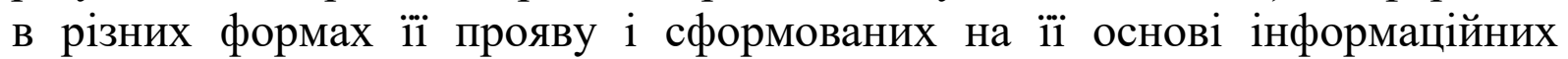
pecypcax; 2) засобах і технологіях роботи з інформацією (інформаційних технологіях); 3) засобах і технологіях комунікації інформації по мережах зв'язку. Дослідниця зазначала, що на основі цієї тріади предметів формується нова галузь суспільних відносин, яка в системі права виділяється в значенні самостійної галузі правового регулювання ${ }^{13}$.

Розділяючи загалом наведену доктринальну позицію, водночас варто зробити важливе застереження, що безпосередньо позначається як на самому розумінні змісту предмета галузі інформаційного права, так і на юрисдикційних підходах до його тлумачення. Йдеться про

\footnotetext{
${ }^{11}$ Талапина Э.В. О предмете информационного права. Государство и право. 2013. № 5. С. 67-68.

12 Буріло Ю.П. Про комплексну природу інформаційного права. Інформація $і$ право. 2015. № 1(13). URL: http://ippi.org.ua/sites/default/files/bypkpip_13_1_2015_0.pdf (дата звернення 29.05.2020).

${ }^{13}$ Бачило И.Л. Информационное право : учебник для академического бакалавриата. 5-е изд., перераб. и доп. Москва : Издательство Юрайт. 2016. С. 23.
} 
неприпустимість ототожнення юридичною сутності понять «інформаційні відносини» та «суспільні відносини, що виникають в інформаційній сфері». «Адже інформація як така є складовою частиною будь-якого типу суспільних відносин. Для інформаційного права важливі лише суспільні відносини, що визначають параметри і характеристики інформаційних процесів, тобто насамперед їх види, форми, засоби, й вже потім змістовне наповнення, яке не завжди має значення для правового регулювання» ${ }^{14}$.

Проникаючи в різні сфери суспільних відносин, інформація, інформаційні ресурси та технології стають інструментами здійснення багатьох видів професійної діяльності: фінансово-господарської, аграрної, медичної, будівельної, транспортної тощо. І лише зв'язок вказаних об'єктів правового регулювання з інформаційною діяльністю, механізмом набуття i реалізації інформаційних прав і свобод надає конкретним суспільним відносинам інформаційно-правової сутності.

«У теорії інформаційного права поняття «інформаційна діяльність» безпосередньо пов'язується, по-перше, 3 процесом пошуку, збирання, зберігання, обробки, поширення, захисту інформації, виробництва інформаційної продукції, надання інформаційних послуг, формування інформаційної інфраструктури, а по-друге, з реалізацією суб'єктивних прав та юридичних обов'язків, задоволенням інформаційних потреб та правомірних інтересів учасників інформаційних відносин» ${ }^{15}$.

Таким чином, для виокремлення 3-поміж усієї сукупності суспільних відносин саме тих, які охоплюються предметом інформаційно-правового регулювання принципово важливого значення набуває зв'язок з інформаційною діяльністю, механізмом набуття або здійснення інформаційних прав чи свобод індивідуальними та колективними суб'єктами права. Тим самим, у процесі викристалізації кола суспільних відносин, що становлять предмет правового регулювання галузі інформаційного права, основний акцент в юридичній інтерпретації їх сутності припадає саме на елементи цих відносин.

Визначаючи правила підвідомчості справ про порушення інформаційних прав фізичних та юридичних осіб судам загальної юрисдикції, норми процесуального законодавства України не використовують поняття «інформаційні відносини» так само, як і не передбачають уніфікованого підходу до визначення сутності їх окремих елементів. Така побудова предметної юрисдикції відповідної категорії справ певною мірою

\footnotetext{
${ }^{14}$ Кормич Б.А. Інформаційне право : Підручник. Харків : «БУРУН і К.», 2011. С. 36.

15 Заярний О.А. Адміністративна деліктологія в інформаційній сфері: проблеми теорії та практики : дис. ... д. юрид. наук : 12.00.07. Київ. Нац. Ун-т імені Тараса Шевченка. Київ, 2018. С. 46.
} 
ускладнює юридичну можливість виокремлення матеріально-правової складової частини предмета галузі інформаційного права.

Водночас аналіз змісту окремих постанов Верховного Суду, винесених за результатами розгляду різних категорій інформаційних спорів ${ }^{16,17}$, дає змогу виокремити низку безпосередніх властивостей інформаційних відносин, акцентуючи на яких, найвищий орган у системі судів загальної юрисдикції фактично формує процесуальне підгрунтя для визначення предмета галузі інформаційного права. Йдеться передусім про суб'єктів спірних правовідносин, їх об'єкт, об'єкт судового захисту, тобто зміст порушених інформаційних прав, свобод та інтересів сторін інформаційного спору, нормативні підстави відкриття провадження у відповідному суді касаційної інстанції тощо. «Призначення Верховного Суду як найвищої судової установи в Україні - це передусім сформувати обгрунтовану правову позицію стосовно застосування всіма судами в подальшій роботі конкретної норми матеріального права або дотримання норми процесуального права, що була неправильно використана, і таким чином спрямувати практику в єдине та правильне правозастосування (вказати напрям, в якому слід здійснювати вибір норми). Крім того, на прикладі конкретної справи роз'яснити зміст акту законодавства в аспекті його розуміння та реалізації на практиці в інших справах з указівкою на обставини, які потрібно враховувати при застосуванні тієї чи іншої правової норми, але не нав'язуючи при цьому нижчим судам результату вирішення конкретної справи» 18 .

Так, зокрема, згідно 3 мотивувальною частиною постанови Великої Палати Верховного Суду від 19.09.2018 р. у зразковій справі N 806/3265/17 (Пз/9901/2/18) за позовом ОСОБА_2 до Коростенського районного відділу Управління Державної міграційної служби України в Житомирській області про визнання протиправною бездіяльності та зобов'язання вчинити певні дії йдеться: «Велика Палата Верховного Суду зазначила, що реалізація державних функцій має здійснюватися без примушення людини до надання згоди на обробку персональних даних, їх обробка має

\footnotetext{
16 Постанова Великої палати Верховного Суду від 19.09.2018 р. у зразковій справі N 806/3265/17 (Пз/9901/2/18) за позовом ОСОБА_2 до Коростенського районного відділу Управління Державної міграційної служби України в Житомирській області, Управління Державної міграційної служби України в Житомирській області про визнання протиправною бездіяльності та зобов'язання вчинити певні дії. URL: https://verdictum.ligazakon.net/document/76822787

17 Постанова колегії суддів Касаційного адміністративного Суду у складі Верховного суду від 26.06.2018 p. № 826/2810/17 за позовом фізичної особи-підприємця ОСОБА_2 до Виконавчого органу Київської міської ради (Київської міської державної адміністрації) про зобов’язання вчинити певні дії. URL: http://advocat-cons.info/index.php?newsid=51404

18 Зуєвич О. (Без) прецедентна ієрархія. Закон $i$ бізнес. 2019. № 21(1723). URL: https://zib.com.ua/ua/print/137890-chi_mozhna_dosyagti_ednosti_sudovoi_praktiki_yakscho_postano.html (дата звернення 29.05.2020).
} 
здійснюватися, як і раніше, в межах і на підставі тих законів і нормативноправових актів України, на підставі яких виникають правовідносини між громадянином та державою. При цьому згадані технології не мають бути безальтернативними і примусовими. Особи, які відмовилися від обробки їх персональних даних, повинні мати альтернативу - використання традиційних методів ідентифікації особи» ${ }^{19}$.

В іншій Постанові від 8 лютого 2019 р. у справі № 855/17/19 (адміністративне провадження № А/9901/15/19) Колегія суддів Касаційного адміністративного суду зазначила, що встановлення певних обмежень щодо доступу до Державного реєстру виборців зумовлене необхідністю забезпечення захищеності реєстру, а це відповідно до ч. 10 ст. 3 Закону України «Про Державний реєстр виборців» означає забезпечення захисту бази даних цього реєстру від несанкціонованого доступу та зловживання доступом. Розглянувши апеляційну скаргу у вказаній справі за позовом кандидата на пост Президента України до Центральної виборчої комісії, колегія суддів Касаційного адміністративного суду у складі Верховного Суду дійшла висновку: «Обов'язок Центральної виборчої комісії надати на вимогу кандидата в Президенти України електронну копію бази даних Державного реєстру виборців кореспондує 3 іншим обов'язком забезпечити належний захист персональних даних виборців, що належать до конфіденційної інформації та захищаються Законом України «Про захист персональних даних» ${ }^{20}$.

Аналіз наведених правових позицій показує, що, наголошуючи на інформаційно-правовій сутності, суб'єктного складу, об'єкта, предмета та змісту спірних правовідносин, Верховний Суд водночас уникає прямого визнання таких відносин інформаційними, а нормативних підстав їх виникнення - актами інформаційного законодавства. Такий правозастосовчий підхід вбачається дискусійним та таким, що веде до ігнорування особливостей спірних правовідносин, які складаються у сфері обігу персональних даних.

Водночас постановка основного акценту на необхідності відновлення права на невтручання в особисте, сімейне життя в процесі виконання державою покладених на неї функцій, межах, цілях, суб'єктах та способах обробки персональних даних, дає підстави вважати, що саме через

\footnotetext{
19 Постанова Великої палати Верховного Суду від 19.09.2018 р. у зразковій справі N 806/3265/17 (Пз/9901/2/18) за позовом ОСОБА_2 до Коростенського районного відділу Управління Державної міграційної служби України в Житомирській області, Управління Державної міграційної служби України в Житомирській області про визнання протиправною бездіяльності та зобов'язання вчинити певні дії. URL: https://verdictum.ligazakon.net/document/76822787 (дата звернення 29.05.2020)

20 Постанова Колегія суддів Касаційного адміністративного суду у складі Верховного Суду від 8 лютого 2019 р. у справі № 855/17/19 (адміністративне провадження № A/9901/15/19). URL: https://supreme.court.gov.ua/supreme/pres-centr/news/646132/ (дата звернення 29.05.2020)
} 
встановлення інформаційно-правової сутності окремих елементів Верховний Суд у такий спосіб визначає належність спірних правовідносин до категорії інформаційних.

У справі за апеляційною скаргою кандидата в Президенти України до Центральної виборчої комісії, про яку йшлося вище, інформаційно-правова сутність спірних правовідносин розкривається також через обов'язок відповідача в цій справі забезпечувати належну охорону персональних даних виборців, що обробляються засобами державного реєстру виборців.

За такого процесуального підходу проблема визначення предмета галузі інформаційного права одержує вирішення через судове доведення юридичного зв'язку конкретних елементів спірних правовідносин 3 інформаційною діяльністю, в результаті здійснення якої і формується предмет відповідної галузі права.

Важливість такого правозастосовчого підходу до оновлення змісту предмета галузі інформаційного права полягає у виробленні правозастосовчих критеріїв викристалізації (виокремлення) групи суспільних відносин, які $є$ інформаційно-правовими за своєю сутністю, відмежування від них саме тих, в яких інформація, інформаційні ресурси чи технології виступають додатковим об'єктом правового регулювання. Прикладом таких правозастосовчих підходів може слугувати висновок Великої Палати Верховного Суду, викладений у постанові від 16.10.2019 р. у справі № 640/6847/15-к (провадження 13-43кс19).

Згідно з цим правовим висновком, якщо сторона обвинувачення під час досудового розслідування своєчасно вжила всіх необхідних та залежних від неї заходів, спрямованих на розсекречення процесуальних документів, які стали підставою для проведення негласних слідчих (розшукових) дій (далі - НСРД), однак такі документи не були розсекречені з причин, що не залежали від волі і процесуальної поведінки прокурора, то суд не може автоматично визнавати протоколи НСРД недопустимими доказами 3 мотивів невідкриття процесуальних документів, якими санкціоноване їх проведення.

Крім того, суд зазначив, що процесуальні документи, які стали підставою для проведення НСРД (ухвали, постанови, клопотання) та які на стадії досудового розслідування не було відкрито стороні захисту в порядку, передбаченому ст. 290 Кримінального процесуального кодексу України з тієї причини, що їх не було в розпорядженні сторони обвинувачення (процесуальні документи не були розсекречені на момент відкриття стороною обвинувачення матеріалів кримінального провадження), можуть бути відкриті іншій стороні під час розгляду справи 
в суді за умови своєчасного вжиття прокурором усіх необхідних заходів для їх отримання.

Якщо сторона обвинувачення не вжила необхідних та своєчасних заходів, що спрямовані на розсекречення процесуальних документів, які стали процесуальною підставою для проведення НСРД і яких немає в іiі розпорядженні, то в такому разі має місце порушення норм ст. 290 КПК України.

Якщо процесуальні документи, які стали підставою для проведення НСРД, розсекречені під час судового розгляду, i сторона захисту в змагальному процесі могла довести перед судом свої аргументи щодо допустимості доказів, отриманих у результаті НСРД, у сукупності 3 оцінкою правової підстави для їх проведення, то суд має оцінити отримані докази та вирішити питання про їх допустимість.

У разі розкриття процесуальних документів, які стали підставою для проведення НСРД після передачі кримінального провадження до суду, суд зобов'язаний забезпечити стороні захисту достатній час і реальну змогу довести перед судом свою позицію щодо належності та допустимості доказів, отриманих у результаті НСРД у комплексі 3 процесуальною підставою для проведення НСРД із метою реалізації принципу змагальності ${ }^{21}$.

Системне тлумачення змісту наведеної правової позиції вказує на те, що спосіб одержання, документування та процесуального представлення інформації, зібраної в процесі проведення НСРД, Велика Палата Верховного Суду в такий спосіб зробила основний акцент не на змісті і правовому режимі інформації, а на процесуальній оцінці дій учасників кримінального процесу. Тим самим Велика Палата Верховного Суду правовим висновком обгрунтувала спеціальні критерії розмежування відносин, що виникають у зв'язку з проведенням НСРД у кримінальному процесі та інформаційних відносин у значенні предмета галузі інформаційного права України.

Таким чином, у процесі розгляду конкретних справ, що підпадають під різні предметні юрисдикції, Верховний Суд у рішеннях встановлює правовий зв'язок конкретних суб'єктів і об'єктів із тим або іншим видом інформаційної діяльності, визначає інформаційно-правову сутність окремих категорії суб'єктивних публічних та приватних прав і свобод. Тим самим Верховний Суд фактично формує у своїй практиці матеріальноправові критерії визначення інформаційних відносин, які можуть

\footnotetext{
21 Постанова Великої Палати Верховного Суду від 16.10.2019 р. у справі № 640/6847/15-к (провадження 13-43кс19). URL: https://supreme.court.gov.ua/supreme/pres-centr/news/805855/ (дата звернення 29.05.2020).
} 
слугувати правовою прикладною основою для оновлення предмета галузі інформаційного права України.

\section{2. Правомірний інтерес учасників інформаційних відносин та розвиток предмета галузі інформаційного права України: основні підходи Верховного Суду}

Поряд 3 оцінкою елементів спірних правовідносин, що становлять предмет галузі інформаційного права, Верховний Суд допускає застосування у своїй практиці також інших критеріїв, в яких розкривається їх прямий зв'язок з інформаційною діяльністю.

Як слідує зі змісту мотивувальної частини постанови Касаційного адміністративного Суду у складі Верховного Суду від 26.06.2018 р. в адміністративній справі № 826/2810/17 за позовом фізичної особипідприємця ОСОБА_2 до Виконавчого органу Київської міської ради (Київської міської державної адміністрації), третя особа без самостійних вимог на предмет спору - Департамент містобудування та архітектури виконавчого органу Київської міської ради (Київської міської державної адміністрації) про зобов'язання вчинити дії за касаційною скаргою Виконавчого органу Київської міської ради (Київської міської державної адміністрації): «Колегія суддів також враховує, що дотримання всіх вимог до розміщення зовнішньої реклами у м. Києві становить значний суспільний інтерес, оскільки столичний статус міста покладає на органи місцевого самоврядування та органи виконавчої влади додаткові обов’язки та гарантує цим органам надання 3 боку держави додаткових прав, зокрема, у сфері здійснення заходів щодо збереження та відновлення пам'яток історії, культури, релігії, архітектури та містобудування, заповідних та природних зон і ландшафтів, що мають національне значення (частина п'ята статті 1, пункт 5 частини першої статті 4 Закону України «Про столицю України - місто-герой Київ»)» 22 .

Пов’язуючи правомірність дій суб'єктів рекламних правовідносин із категорією «суспільного інтересу», Касаційний адміністративний суд у складі Верховного Суду тим самим встановив безпосередній зв'язок між результатами реалізації інформаційних відносин та суспільним інтересом щодо задоволення інформаційних потреб жителів територіальної громади.

В іншій Постанові Колегія суддів Касаційного адміністративного суду у складі Верховного Суду від 18 липня 2019 р. у справі № 554/11837/14-а сформував правовий висновок: «Інформація, пов’язана 3 виконанням умов

\footnotetext{
22 Постанова колегії суддів Касаційного адміністративного Суду у складі Верховного суду від 26.06.2018 p. № 826/2810/17 за позовом фізичної особи-підприємця ОСОБА_2 до Виконавчого органу Київської міської ради (Київської міської державної адміністрації) про зобов’язання вчинити певні дії. URL: http://advocat-cons.info/index.php?newsid=51404 (дата звернення 29.05.2020).
} 
договору про інвестиційну (пайову) участь у будівництві, що здійснюється за рахунок земель комунальної власності та бюджетних коштів, не $\epsilon$ конфіденційною, не може бути обмежена в доступі умовами жодного договору та підлягає наданню на запит, оскільки доступ до такої інформації вже санкціонований законом і не потребує згоди сторін, які підписали умови такого договору.

У зазначеній справі Верховний Суд звернув увагу на те, що у ч. 2 ст. 6 Закону України «Про доступ до публічної інформації» передбачено вимоги до обмеження доступу до інформації, а не підстави для надання такого доступу. Такий підхід грунтується на тому, що ст. 1 цього Закону закріплена презумпція відкритості публічної інформації, доступ до якої може бути обмеженим лише у разі, якщо розпорядник інформації обгрунтує це на підставі «трискладового тесту». Отже, тягар доведення того, що доступ до інформації може бути обмежений, покладається на розпорядника публічної інформації» ${ }^{23}$.

Покладаючи тягар обгрунтування необхідності зарахування публічної інформації до категорії конфіденційної на іiі розпорядника та пов'язуючи відповідні дії 3 обов'язковим проведенням трискладового тесту, Касаційний адміністративний суд у такий спосіб зробив основний акцент на необхідності забезпечення суспільного інтересу, пов'язаного 3 правом кожного на ознайомлення 3 інформацією щодо використання об'єктів комунальної власності.

Варто зазначити, що в практиці Верховного Суду категорія «інтерес» часто використовується і щодо суб'єктів приватного права для цілей визначення інформаційно-правової сутності спірних відносин. Так, наприклад, 20 березня 2019 р. Касаційний цивільний суд у складі Верховного Суду розглянув справу за позовом ОСОБА_3 до ОСОБА_4, третя особа - Громадська організація «Об'єднання українсько-чеченської дружби», про захист честі, гідності та ділової репутації, сформулював правову позицію: «Правом на звернення до суду за захистом наділена особа в разі порушення, невизнання або оспорювання саме ії прав, свобод чи інтересів, а також у разі звернення до суду органів і осіб, уповноважених захищати права, свободи та інтереси інших осіб або державні та суспільні інтереси. Під час розгляду спору суд повинен установити, чи були порушені, не визнані або оспорені права, свободи чи інтереси цих осіб, і залежно від установленого вирішити питання про задоволення позовних вимог або відмову в їх задоволенні. У зазначеній

\footnotetext{
23 Постанова Колегії суддів Касаційного адміністративного суду у складі Верховного Суду від 18 липня 2019 р. у справі № 554/11837/14-a. URL: http://reyestr.court.gov.ua/Review/83105365 (дата звернення 29.05.2020).
} 
справі позивач не довів порушення його прав, оскільки інформація, що була розміщена в соціальній мережі Facebook, стосується ГО «Об'єднання українсько-чеченської дружби», яка в цій справі залучена як третя особа. При цьому та обставина, що позивач $є$ керівником ГО «Об'єднання українсько-чеченської дружби», не $\epsilon$ підставою вважати порушенням прав позивача, оскільки він звернувся до суду із цим позовом як фізична особа, а не як керівник зазначеної громадської організації з метою представлення iї інтересів та захисту ділової репутації» ${ }^{24}$.

Застосовуючи категорію «інтерес» у процесі кваліфікації спірних правовідносин, Верховний Суд визначає коло соціальних цінностей, включаючи правомірні потреби учасників інформаційних відносин, які вимагають правового захисту і відновлення.

Варто зазначити, в окремих справах Верховний Суд у процесі вирішення спору одночасно вдається до судового тлумачення не лише характеру охоронюваного законом інтересу, але й окремих елементів спірних правовідносин. У такий спосіб найвищий орган у системі судів загальної юрисдикції встановлює матеріально-правовий зв'язок між правовим статусом суб'єктів відносин, з яких виник спір, та змістом їх інтересів, для захисту яких сторони судового процесу ініціюють касаційний перегляд конкретної справи Верховним Судом.

Так, в одній зі справ, розглянутій Великою Палатою Верховного Суду, зазначено: «Особа звернулася до Національної бібліотеки України 3 інформаційним запитом, в якому просила надати копію штатного розпису Бібліотеки та копії наказів, якими внесено зміни до порядку (режиму) роботи установи та обслуговування користувачів. Бібліотека відмовила заявнику в наданні вказаних документів, зазначивши, що предмет його запиту не можна зарахувати до публічної інформації.

Окружний адміністративний суд позов задовольнив, натомість суд апеляційної інстанції скасував відповідну постанову та закрив провадження в адміністративній справі, керуючись тим, що Бібліотека не $\epsilon$ суб'єктом владних повноважень.

Водночас відповідач - розпорядник публічної інформації щодо використання бюджетних коштів. Однак з огляду на те, що інформація, про надання якої йдеться в запиті позивача, не стосується використання Бібліотекою бюджетних коштів, вона не є публічною. Апеляційний суд вирішив, що спірні правовідносини не є публічно-правовими, а тому справа підлягає розгляду за правилами цивільного судочинства.

\footnotetext{
${ }^{24}$ Постанова Касаційного цивільного суду у складі Верховного Суду від 20 березня 2019 р. у справі N 522/16923/16 (провадження N 61-29689св18). URL: http://www.reyestr.court.gov.ua/Review/80854281 (дата звернення 29.05.2020).
} 
Такий висновок Велика Палата Верховного Суду визнала помилковим. Зміст запит свідчить, що підставою для звернення стало розміщене в приміщенні Бібліотеки оголошення про зміну режиму обслуговування користувачів через гостру необхідність економії коштів на оплату енергоносіїв та комунальних послуг.

Отже, звернення позивача безпосередньо пов'язане 3 використанням відповідачем бюджетних коштів. При цьому суд зауважив, що запитуваний позивачем штатний розпис Бібліотеки - це документ, що застосовується в процесі виконання бюджету.

Велика Палата Верховного Суду дійшла висновку, що у справі наявний спір між фізичною особою та розпорядником публічної інформації щодо оскарження дій (бездіяльності) у частині доступу до публічної інформації, a тому 3 огляду на прямий припис процесуального закону цей спір підпадає під юрисдикцію адміністративних судів» ${ }^{25}$.

Аналіз змісту наведеної постанови Великої Палати Верховного Суду вказує на те, що в окремих категоріях справ встановлення юридичного зв'язку між правовим статусом сторін спірних правовідносин, їхніми інтересами і потребами за конкретних обставин може істотно позначатися на інституційній належності тих або інших інформаційних відносин. У цьому конкретному випадку застосовані Верховним Судом критерії до кваліфікації спірних правовідносин зумовили їхню пряму належність до інституту публічної інформації, дали змогу правильно визначити предметну юрисдикцію відповідного спору.

Таким чином, поряд 3 елементами інформаційних відносин, за правовими позиціями Верховного Суду, категорія «інтерес» виступає окремим критерієм для встановлення інформаційно-правової сутності спірних правовідносин.

\section{ВИСНОВКИ}

Проведене дослідження показало, що Верховний Суд здійснює практичний вплив на формування предмета галузі інформаційного права шляхом визнання інформаційно-правової сутності за окремими елементами спірних відносин, встановлення юридичного зв'язку між суспільним або приватним інтересом, наявним в інформаційній сфері, та результатами інформаційної діяльності.

Виокремлення в практиці Верховного Суду вказаних критеріїв має поряд із власне практичним важливе теоретичне значення. Воно полягає в тому, що вироблені судами касаційної інстанції різних юрисдикцій

\footnotetext{
${ }^{25}$ Постанова Великої палати Верховного Суду від 27 березня 2019 р. у справі № 826/25885/15. URL: http://www.reyestr.court.gov.ua/Review/81329464 (дата звернення 29.05.2020).
} 
критерії зарахування суспільних відносин до категорії інформаційних сприяють формуванню основних комплексних інститутів галузі інформаційного права. 3 іншого боку, через наукове дослідження правозастосовчих критеріїв формування предмета галузі інформаційного права, в юридичній науці розвиваються процеси, пов'язані 3 відмежуванням від предмета регулювання вказаної галузі права тих суспільних відносин, які не є інформаційними за своєю сутністю.

При цьому в умовах поступового виокремлення правозастосовчих критеріїв визначення предмета галузі інформаційного права України важливим завданням для Верховного Суду є забезпечення усталеності підходів до вирішення конкретних категорії інформаційних спорів. Адже за умови мінімізації випадків відступу Верховного Суду від раніше сформульованих правових позицій, глибокого, аргументованого обгрунтування інформаційно-правової сутності спірних відносин, пов'язаних із порушенням норм інформаційного законодавства, вироблені найвищим органом у системі судів загальної юрисдикції критерії визначення предмета галузі інформаційного права набувають ознак правової визначеності і універсальності. Тим самим у національній правовій системі України створюються необхідні передумови для зближення інформаційноправової доктрини та судової практики в контексті оновлення предмета вітчизняної галузі інформаційного права, модернізації більшості іiі правових інститутів.

\section{АНОТАЦІя}

У роботі проведене дослідження основних векторів взаємозв'язку між доктринальними підходами до визначення предмета інформаційного права як галузі національного права України та рішеннями Верховного Суду у справах про порушення норм інформаційного законодавства, проаналізовано вплив судового розсуду на оцінку сутності інформаційних відносин як однієї з ключових категорій інформаційного права. На цій основі автором обгрунтовані критерії, за якими відбувається практичний вплив рішень Верховного Суду на процеси оновлення змісту предмета галузі інформаційного права України, надано розгорнуту теоретико-прикладу характеристику цим критеріям.

Предметом окремої уваги в роботі стала проблематика комплексної природи галузі інформаційного права та підвідомчість інформаційних спорів судам усіх касаційних інстанцій у контексті правозастосовчого тлумачення елементів інформаційних відносин, суспільного інтересу в інформаційній сфері та змісту інформаційної діяльності. 
У висновках за результатами проведеного дослідження обгрунтовано необхідність вироблення у практиці Верховного Суду універсальних критеріїв виокремлення із категорій спірних публічних та приватних правовідносин тих, які мають інформаційно-правову сутність, формування на цій основі практичних засад побудови основоположних складників галузі інформаційного права України.

\section{ЛІТЕРАТУРА}

1. Заярний О.А. Інформаційна сфера як об'єкт адміністративно-правової охорони: деякі доктринальні та нормативні аспекти. Журнал східноєвропейського права. № 22. URL: http://easternlaw.com.ua/uk/osobliveadministrativne-pravo/zayarnij-o-a-informacijna-sfera-yak-obyekt-administrativnopravovo\%D1\%97-oxoroni-deyaki-doktrinalni-ta-normativni-aspekti

2. Бєляков К.І. Інформаційне право: аналіз понятійно-терміналогічного апарату. Вісник Національної академї внутрішніх справ. 2007. № 3. C. $67-72$.

3. Загальна теорія права : підручник / За заг. ред. М.І. Козюбри. Київ : Ваіте. 2015. 392 c.

4. Загальна теорія держави і права [Текст]: підручник для студентів юридичних вищих навчальних закладів / [М.В. Цвік, О.В. Петришин, Л.В. Авраменко та ін.]; за ред. д-ра юрид. наук, проф., акад. АПрН України М.В. Цвіка, д-ра юрид. наук, проф., акад. АПрН України О.В. Петришина. Харків : Право, 2009. 584 с.

5. Буріло Ю.П. Про комплексну природу інформаційного права. Інформачія і право. 2015. № 1(13). URL: http://ippi.org.ua/sites/default/files/ bypkpip_13_1_2015_0.pdf (дата звернення 29.05.2020).

6. Заярний О.А. Правове забезпечення розвитку інформаційної сфери України: адміністративно-деліктний аспект : монографія. Херсон : Видавничий дім «Гельветика». 2017. 700 с.

7. Про судоустрій і статус суддів : Закон України від 02.06.2016 p. № 1402-VIII. Голос України. 2016. № 132/133.

8. Господарський процесуальний кодекс України від 06.11.1991 p. (редакція від 28.08.2018). URL: https://zakon.rada.gov.ua/laws/show/1798-12. (дата звернення: 29.09.2020).

9. Кодекс адміністративного судочинства України від 06.07.2005 p. (редакція від 04.11.2018). URL: https://zakon.rada.gov.ua/laws/show/2747-15 (дата звернення: 29.05.2020).

10. Цивільний процесуальний кодекс України : Закон України від 18.03.2004 p. № 1618-IV (редакція від 04.11.2018). URL: https://zakon.rada.gov.ua/laws/show/1618-15 (дата звернення: 29.05.2020). 
11. Талапина Э.В. О предмете информационного права. Государство $и$ право. 2013. № 5. С. 67-72.

12. Бачило И.Л. Информационное право : учебник для академического бакалавриата. 5-е изд., перераб. и доп. Москва : Издательство Юрайт, 2016. 419 c.

13. Кормич Б.А. Інформаційне право : Підручник. Харків : «БУРУН і К.», $2011.334 \mathrm{c}$.

14. Заярний О.А. Адміністративна деліктологія в інформаційній сфері: проблеми теорії та практики : дис. ... д. юрид. наук : 12.00.07. Київ. Нац. Ун-т імені Тараса Шевченка. Київ, 2018. 561 с.

15. Постанова Великої палати Верховного Суду від 19.09.2018 р. у зразковій справі N 806/3265/17 (Пз/9901/2/18) за позовом ОСОБА_2 до Коростенського районного відділу Управління Державної міграційної служби України в Житомирській області, Управління Державної міграційної служби України в Житомирській області про визнання протиправною бездіяльності та зобов'язання вчинити певні діï. URL: https:// verdictum.ligazakon.net/document/76822787 (дата звернення 29.05.2020).

16. Постанова колегії суддів Касаційного адміністративного Суду у складі Верховного суду від 26.06.2018 р. № 826/2810/17 за позовом фізичної особи-підприємця ОСОБА_2 до Виконавчого органу Київської міської ради (Київської міської державної адміністрації) про зобов'язання вчинити певні діiі. URL: http://advocat-cons.info/index.php?newsid=51404 (дата звернення 29.05.2020).

17. Зуєвич О. (Без) прецедентна ієрархія. Закон $i$ бізнес. 2019. № 21(1723). URL: https://zib.com.ua/ua/print/137890chi_mozhna_dosyagti_ ednosti_sudovoi_praktiki_yakscho_postano.html (дата звернення 29.05.2020).

18. Постанова Колегія суддів Касаційного адміністративного суду у складі Верховного Суду від 8 лютого 2019 р. у справі № 855/17/19 (адміністративне провадження № A/9901/15/19). URL: https:// supreme.court.gov.ua/supreme/pres-centr/news/646132/ (дата звернення 29.05.2020).

19. Постанова Великої Палати Верховного Суду від 16.10 .2019 р. у справі № 640/6847/15-к (провадження 13-43кс19). URL: https:// supreme.court.gov.ua/supreme/pres-centr/news/805855/ (дата звернення 29.05.2020).

20. Постанова Колегії суддів Касаційного адміністративного суду у складі Верховного Суду від 18 липня 2019 р. у справі № 554/11837/14-а. URL: http://reyestr.court.gov.ua/Review/83105365 (дата звернення 29.05.2020).

21. Постанова Касаційного цивільного суду у складі Верховного Суду від 20 березня 2019 p. у справі N 522/16923/16 (провадження 
№ 61-29689св18). URL: http://www.reyestr.court.gov.ua/Review/80854281 (дата звернення 29.05.2020).

22. Постанова Великої палати Верховного Суду від 27 березня 2019 р. у справі № 826/25885/15. URL: http://www.reyestr.court.gov.ua/Review/ 81329464 (дата звернення 29.05.2020).

Information about author:

Zaiarnyi O. A., Dr. Habil. (Law), Associate Professor of the Administrative Law Department of the Faculty of Law Taras Shevchenko National University of Kyiv 60, Volodymyrska Str., Kyiv, 01033, Ukraine 